\title{
Effect of Silica Fume on Fly Ash Cement Bricks - An Experimental Study
}

\author{
Saurabh Samander ${ }^{1}$, Dr. Arun Kumar Dwivedi ${ }^{2}$, \& Sangeeta D.Agarwal ${ }^{3}$ \\ ${ }^{I}$ : Director, ILLUMINE Construction \& Consultancy Services, Indore, MP, India \\ 2 : Professor \& Head, Department of Civil Engg., SSVPS BSD College of Engineering, Dhule, MS, India \\ ${ }^{3}$ : Assistant Professor, Department of Civil Engg., SSVPS BSD College of Engineering, Dhule, MS, India
}

\begin{abstract}
This investigation is done to study of the effect of silica fume on fly ash cement bricks. The experiments are conducted in two phases to observe the variation in properties i.e. compressive strength, density and water absorption of fly ash-cement brick. In first phase the fly ash, stone dust percentage are kept constant and cement is replaced with silica fume in different proportion, whereas in second phase, silica fume is added as a admixture in same proportion of weight of cement. The entire experimentation is done S.M. Nawle \& Company fly ash - cement brick plant in Dhule. The fly ash cement - bricks are tested after 7 days, 14 days and 28 days curing in concrete material testing laboratory of the institute. The experimental results showed that in the compressive strength of fly ash cement brick decreases with increase in content of silica fumes as replacement of cement whereas increases with increase in content of silica fume as addition. The water absorption \% in first phase of experimentation increases whereas in second phase of experimentation decreases.
\end{abstract}

Keywords - Bricks, Compressive Strength, Fly Ash, Silica Fume, Water Absorption.

\section{Background}

India is the second largest producer of bricks after china. The estimated brick production during 201112 was close to 200 billion. The Indian brick industry is unrecognized with small production units clustered in rural and peri-urban areas. There are more than 100,000 brick kilns operating in the country. The brick making consumes about 24 million tons of coal and several million tones of biomass fuels per year. The coal consumption by the brick industry is approximately $8 \%$ of the total coal in the country. The share of energy cost in total costs of brick production is 35 to $50 \%$. Several types of brick kilns are used for firing bricks. The choice of technology depends generally on factors such as scale of production, soil and fuel availability market conditions and skills.

\section{Fly Ash - Cement Brick Making Process}

The process for manufacturing fly ash - cement/lime brick requires fly ash, sand/stone dust, and cement/lime and gypsum which are mixed in proper proportion. Firstly lime and gypsum mixed in pan-mixer with optimum quantity of water. Then fly ash and sand/stone dust are further mixed in to pan-mixer to form homogeneous mixture. In the place of lime and gypsum if cement is used, initially in pan-mixer fly ash and sand/stone dust are mixed and after this cement is added into pan-mixer to form homogeneous dry mixture. The optimum quantity of water added in to pan-mixer until homogeneous dry mixture of fly ash, sand/stone dust and cement are achieved. The mixture is then transferred to the molding machine via belt conveyor and is pressed or compacted. If hydraulic press is used, the bricks are formed at a pressure of $150-200 \mathrm{~kg} / \mathrm{cm}^{2}$. The pressed bricks are taken out manually and are laid on wooden pallet in 4-5 layers. The brick laden pallets are transported on hydraulic trolley from press area to stack yard. If vibratory press is used, the mix is manually brought from the pan-mixer and filled into the moulds. The table, on which the moulds are kept, is vibrated. The mix is also pressed lightly. The pallets from the table with the bricks are taken manually to stack yard. The bricks are air dried for about 1 to 2 days and then cured at least for 14 days to achieve its required strength. The curing is carried out by sprinkling water manually or by any other means. It is recommended that the curing period may be extended during cold/wet weather. The process of making the fly-ash cement brick is shown in Figure -1 . 


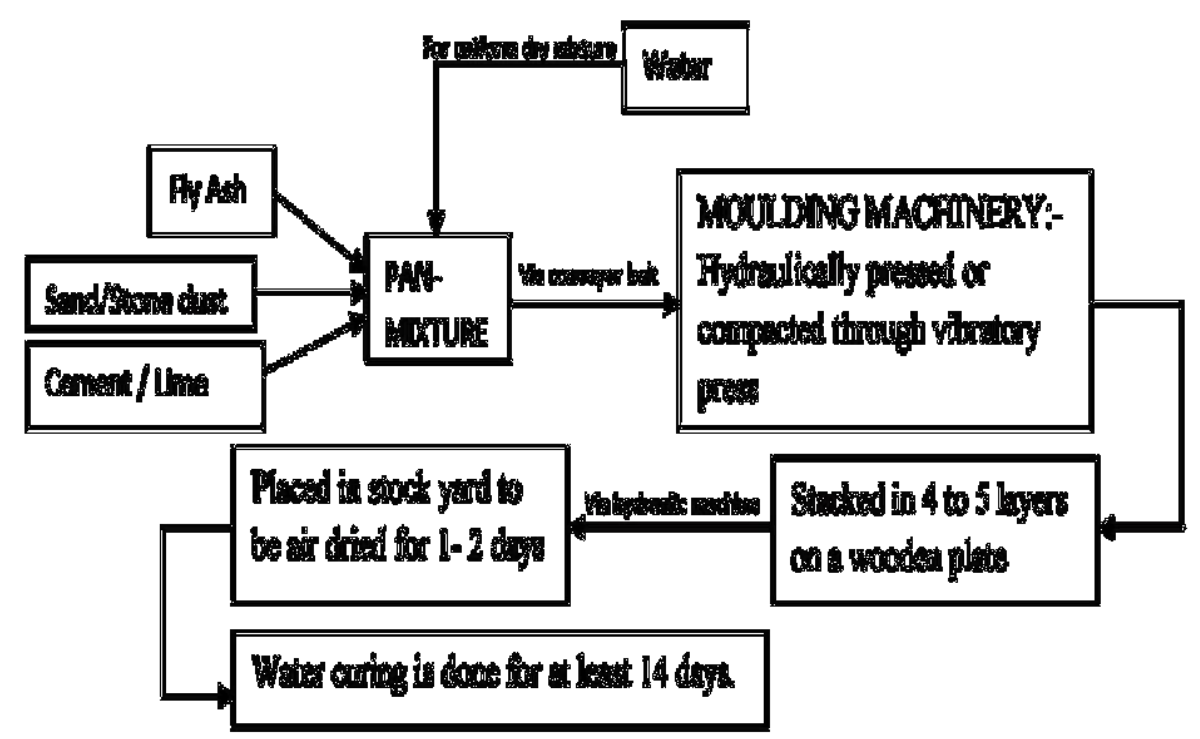

Figure - 1: Flow Chart Showing Fly Ash - Cement Brick Making Process

\section{Experimental Work}

An attempt is made to study the effect of silica fume on the properties of fly ash cement bricks. The silica fume for this purpose is taken from the Oriental Pvt. Ltd. Navi Mumbai and fly ash is made available from S. M. Nawle \& Company, Dhule, MS, India, who are the manufacturer of fly ash cement brick and all the experimentation is done at same place. The testing of the bricks is done at the concrete material testing laboratory of SSVPS' BSD College of Engineering, Deopur, Dhule, MS, India.

The experimentation is done in two phases. In phase-I, the mixture's proportions of fly ash and stone dust is kept constant, whereas, the cement is replaced by silica fumes in different proportions by weight of cement as shown in Table -1 . These mixtures of different proportions are mixed thoroughly by adding the appropriate amount of water in pan mixer. The prepared mixes are then put into the mould of hydraulic pressing machine. The ready bricks from the mixes of different proportions are marked as S-I-1 to S-I-5 so as to be identified at the time of testing.

A parallel experiment is carried for i.e. phase-II, where instead of replacing the cement with silica fume, cement proportion is kept constant and silica fume is added in the mixture in different proportions as shown in Table -1 . The bricks are prepared from these different mixes as discussed earlier and are marked from number S-II-1 to S-II-5 so as to be identified at the time of testing.

Table - 1 : Mix proportions of bricks for Phase - I \& II

\begin{tabular}{|c|c|c|c|c|c|c|c|c|c|c|}
\hline \multirow{3}{*}{ Sr. No. } & \multirow{2}{*}{$\begin{array}{c}\text { Mix } \\
\text { Designation }\end{array}$} & \multicolumn{6}{|c|}{ Constituent Materials (in Kg) } \\
\cline { 2 - 11 } & Phase - I I & Phase - II & $\begin{array}{c}\text { Fly } \\
\text { Ash }\end{array}$ & Cement & $\begin{array}{c}\text { Stone } \\
\text { Dust }\end{array}$ & $\begin{array}{c}\text { Silica } \\
\text { Fume }\end{array}$ & $\begin{array}{c}\text { Fly } \\
\text { Ash }\end{array}$ & Cement & $\begin{array}{c}\text { Stone } \\
\text { Dust }\end{array}$ & $\begin{array}{c}\text { Silica } \\
\text { Fume }\end{array}$ \\
\cline { 2 - 11 } & S-I-1 & S-II-1 & 58.00 & 10.00 & 32.00 & 0.00 & 58.00 & 10.00 & 32.00 & 0.00 \\
\hline 1 & S-I-2 & S-II-2 & 58.00 & 9.25 & 32.00 & 0.75 & 58.00 & 10.00 & 32.00 & 0.75 \\
\hline 2 & S-I-3 & S-II-3 & 58.00 & 9.00 & 32.00 & 1.00 & 58.00 & 10.00 & 32.00 & 1.00 \\
\hline 3 & S-I-4 & S-II-4 & 58.00 & 8.75 & 32.00 & 1.25 & 58.00 & 10.00 & 32.00 & 1.25 \\
\hline 4 & S-I-5 & S-II-5 & 58.00 & 8.50 & 32.00 & 1.50 & 58.00 & 10.00 & 32.00 & 1.50 \\
\hline 5 & & & & & & & & & & \\
\hline
\end{tabular}

A total of 300 bricks are made, which includes minimum 30 bricks for each proportion of mixes in both phases of experimentation. The prepared bricks are dried in a shaded area with open surroundings for 2 days. After setting the bricks are cured by water, by the traditional process i.e. putting jute bags on them and then keeping them wet by sprinkling with water. These bricks are tested in three stages i.e. after 7 days, 14 days and 28 days curing. All the tests on bricks are conducted in the concrete testing laboratory of SSVPS' BSD College of Engineering, Deopur, Dhule, MS, India. These tests i.e. compressive strength and water absorption are conducted as per BIS procedure mentioned in IS 3495 (part I):1992, IS 3495(part II):1992, IS 3495(part III):1992, IS 12894:2002. 


\section{Compressive Strength Test}

\section{Observations}

The compressive strength test for phase I and phase II is carried out after 7, 14 and 28 days curing. The dimensions of all sample bricks are measured and the average dimension was taken for the calculation of the compressive strength. The average dimensions of the bricks are observed as $230 \times 100 \times 77 \mathrm{~mm}$. The results of compressive strength test are shown in Table -2 .

Table - 2 : Results of Compressive Strength Test

\begin{tabular}{|c|c|c|c|c|c|c|c|}
\hline \multirow{3}{*}{ Mix } & \multirow{2}{*}{\multicolumn{3}{|c|}{$\begin{array}{c}\text { Average Compressive Strength in N/mm } \\
\text { PHASE - I }\end{array}$}} & \multirow{3}{*}{ Mix } & \multirow{2}{*}{\multicolumn{3}{|c|}{$\frac{\text { Average Compressive Strength in } \mathrm{N} / \mathrm{mm}^{2}}{\text { PHASE - II }}$}} \\
\hline & & & & & & & \\
\hline & 7 Day & 14 Day & 28 Day & & 7 Day & 14 Day & 28 Day \\
\hline S-I-1 & 3.16 & 7.16 & 7.59 & S-II-1 & 3.16 & 7.16 & 7.59 \\
\hline S-I-2 & 3.24 & 7.50 & 7.67 & S-II-2 & 3.67 & 7.50 & 8.02 \\
\hline S-I-3 & 2.98 & 6.48 & 6.91 & S-II-3 & 3.67 & 8.53 & 8.87 \\
\hline S-I-4 & 2.56 & 5.12 & 5.80 & S-II-4 & 5.97 & 8.95 & 9.38 \\
\hline S-I-5 & 1.96 & 3.92 & 4.60 & S-II-5 & 6.05 & 9.21 & 9.55 \\
\hline
\end{tabular}

\section{Water Absorption Test}

The water absorption test for phase-I and phase-II is carried out on bricks after 28 days curing. The results expressed in terms of water absorption in \%, dry and wet densities are shown in Table -3 .

Table - 3 : Results of Water Absorption, Dry and Wet Densities

\begin{tabular}{|c|c|c|c|c|c|c|c|}
\hline \multirow[b]{2}{*}{ Mix } & \multicolumn{3}{|c|}{ PHASE - I } & \multirow[b]{2}{*}{ Mix } & \multicolumn{3}{|c|}{ PHASE - II } \\
\hline & $\begin{array}{c}\text { Average } \\
\% \text { Water } \\
\text { Absorption }\end{array}$ & $\begin{array}{c}\text { Average } \\
\text { Dry } \\
\text { Density } \\
\text { in } N / m 3\end{array}$ & $\begin{array}{c}\text { Average } \\
\text { Wet } \\
\text { Density } \\
\text { in } \mathrm{N} / \mathrm{m} 3\end{array}$ & & $\begin{array}{c}\text { Average } \\
\% \text { Water } \\
\text { Absorption }\end{array}$ & $\begin{array}{c}\text { Average } \\
\text { Dry } \\
\text { Density } \\
\text { in N/m3 }\end{array}$ & $\begin{array}{c}\text { Average } \\
\text { Wet } \\
\text { Density } \\
\text { in N/m3 }\end{array}$ \\
\hline S-I-1 & 14.00 & 13029.95 & 14858.55 & S-II-1 & 14.00 & 13029.95 & 14858.55 \\
\hline S-I-2 & 15.19 & 12754.28 & 14691.31 & S-II-2 & 9.60 & 14542.45 & 15937.34 \\
\hline S-I-3 & 16.71 & 12607.26 & 14711.53 & S-II-3 & 8.19 & 14318.24 & 15492.59 \\
\hline S-I-4 & 20.35 & 12423.48 & 14952.28 & S-II-4 & 7.87 & 13417.72 & 14472.62 \\
\hline S-I-5 & 22.68 & 12381.21 & 15176.49 & S-II-5 & 7.70 & 13092.43 & 14101.38 \\
\hline
\end{tabular}

\section{Water Absorption -}

\section{Result and Analysis}

The variation in water absorption $\%$, in fly ash cement bricks after 28 day curing, for different mixes, prepared in phase-I \& II are shown in Figure - 2. The \% water absorption in phase - I, increases with increase in replacement of cement by silica fume, where as in phase - II, the $\%$ water absorption decreases with increase in addition of silica fumes. The $\%$ water absorption in phase-I increases by $62 \%$ for mix S-I-5 with respect to S-I1 , whereas in phase-II it decreases by $44.99 \%$ for S-II- 5 with respect to S-II-1.

\section{Dry density}

The variation in dry density of fly ash bricks after 28 days curing, for different mix for both phases is shown in Figure - 3. In case of phase - I, the dry density decreases with increase in silica fume replacement for cement, whereas for phase-II, the dry density increases with addition of silica fume initially and decreases thereafter. The dry density in II phase increases with respect to mix S-II-1, maximum by $11.61 \%$ for mix S-II-2 and $9.89 \%, 2.98 \%$ and $0.48 \%$ for mix S-II-3, S-II-4 and S-II-5. Whereas for phase-I, the dry density decreases for mix S-I-2, S-I-3, S-I-4 and S-I-5 by $2.12 \%, 3.14 \%, 4.65 \%$ and $4.98 \%$ respectively. 




Figure - 2 : Variation in Water Absorption (\%) for different mixes

\section{Compressive Strength}

The compressive strength of the fly ash bricks for both the phases for different mixes is plotted and is shown in Figure - 4. The compressive strength decreases when cement is replaced with silica fume whereas it increases with the addition of silica fume. It is clear from Figure -4 that the compressive strength of fly ash bricks increases gradually with increase in silica fume in phase-II. In phase-I, the compressive strength of the mix S-I-2 is almost same as of mix S-I-1, whereas it starts decreasing thereafter and is 39.33\% less for S-I-5 than mix S-I-1. However in phase-II, the compressive strength increases gradually for the mixes S-II-2 to S-II-5 and increases by $25.83 \%$ for S-II-5 with respect to S-II-1.

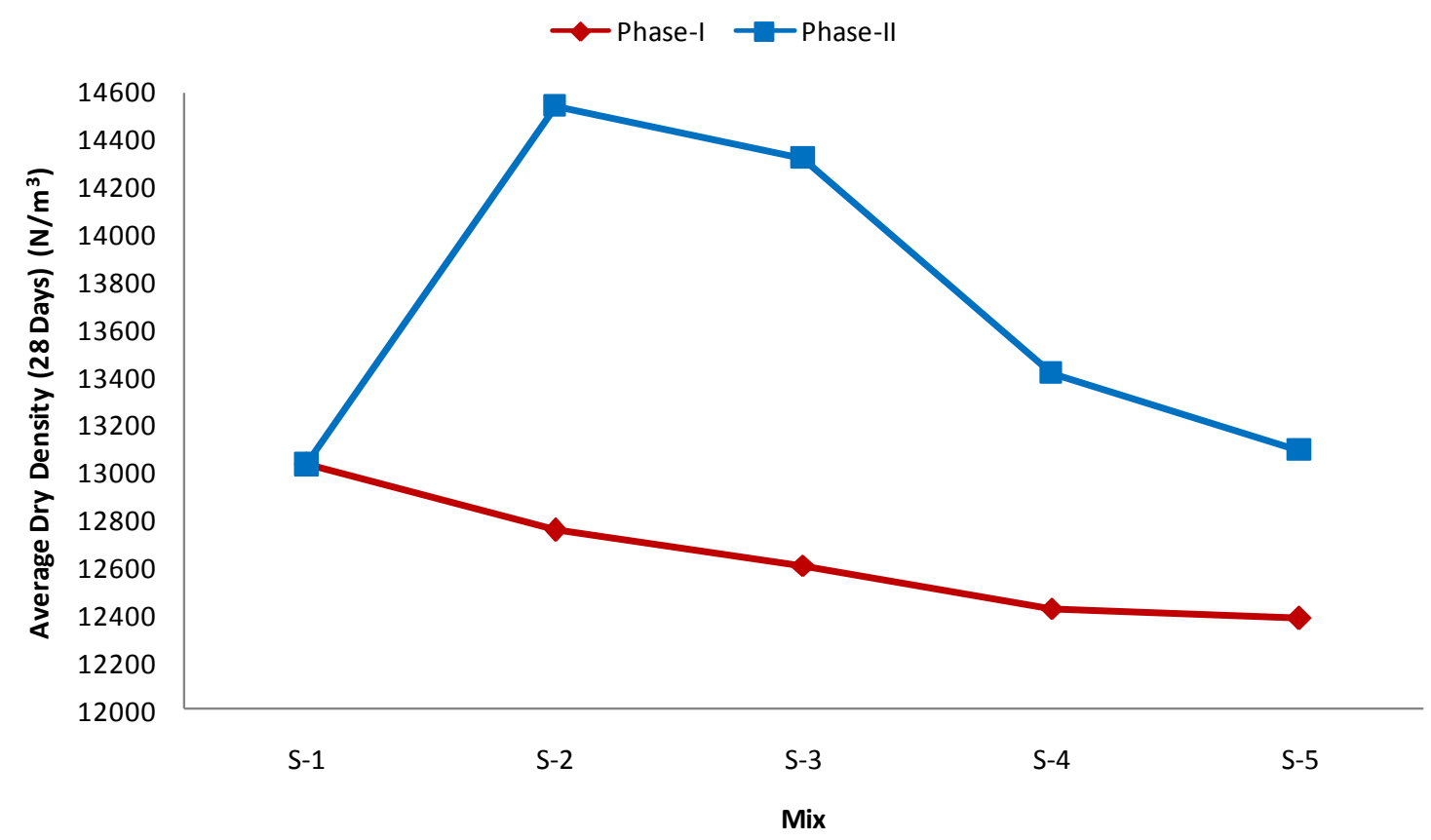

Figure - 3 : Variation in Dry Density for different mixes 




Figure - 4 : Variation in Compressive Strength for different mixes

\section{Conclusions}

The following conclusions are drawn from the experimental study conducted in two phases; i.e. in phase-I the silica fume is used as replacement for cement and in phase-II the silica flume is added in the mix.

- The water absorption characteristics of bricks become poor, when the cement is replaced by the silica fumes; however it gets improved when the silica fume is added in mix.

- The dry densities of the bricks reduce when the cement is replaced by the silica fumes. In case of addition of silica fume, the dry density increases; however the optimum dry density corresponds to mix S-II-2.

- The compressive characteristics of bricks degrade with the replacement of cement by the silica fumes; however it gets improved when the silica fume is added in mix.

- The silica fume proves to be not a replacement of cement; improves the overall properties of the fly ash cement bricks when used as an additive.

\section{REFERENCES}

[1]. Akhtar, J.N. et. al. (2011), "Bricks with Total Replacement of Clay by Fly Ash Mixed With Different Materials", International Journal of Engineering Science and Technology (IJEST), Vol. 3, No.10 October 2011

[2]. Gamal, A. A. (2012), "Utilization of Perlite and Foam in Cement Bricks", Journal of Applied Sciences Research, ISSN 1819544X.2012, 8(7), pp : 3112-3121,

[3]. Hegazy, B El-Din E. et. al. (2011), "Reuse of Water Treatment Sludge and Silica Fume in Brick Manufacturing", Journal of American Science, 2011.

[4]. Holland, T.C. (2005), "Silica Fume User's Manual”, Silica Fume Association, Federal Highway Association, FHWA-IF-05-016.

[5]. IS-12894 : 2002, "Pulverized Fuel Ash-Lime Bricks - Specification”, First Revision, Bureau of Indian Standards, Manak Bhavan, 9, Bahadur Zafar Marg, New Delhi 110002.

[6]. IS-3495 : 1992 (Part 1 to 4), "Method Of Testing Of Burnt Clay Building Bricks", First Revision, Bureau of Indian Standards, Manak Bhavan, 9 Bahadur Zafar Marg, New Delhi 110002.

[7]. IS-5454 : 1978,"Method for Sampling of Clay Building Bricks”, First Revision, Bureau of Indian Standards, Manak Bhavan, 9 Bahadur Zafar Marg, New Delhi 110002.

[8]. Kocak Y. (2010), "A Study on the Effect of Fly Ash and Silica Fume Substituted Cement Paste and Mortars", Scientific Research and Essays, ISSN 1992-2248, Vol. 5(9), pp. 990-998.

[9]. Parashar, A.K. \& Parashar, R. (2012), "Comparative Study of Compressive Strength of Bricks Made With Various Materials to Clay Bricks", International Journal of Scientific and Research Publications, Volume 2, Issue 7, July 2012.

[10]. Tabin Rushad S. et. al. (2011), "Experimental Studies on Lime-Soil-Fly Ash Bricks", International Journal of Civil and Structural Engineering, Volume 1, No 4, 2011. 